mechanisms. An attempt has been made to incorporate recent advances in neurology, but the book is not fully up to date; cerebral angiography (with thorotrast) is mentioned in the section on cerebral tumours and the latest reference to this procedure appears to be one dated 1935 .

Proof correction has been imperfect; thus on page 52 'penicillin is sensitive to the pneumococcus' and on page 70 'rigour' is written for 'rigor.'

The book is entirely lacking in a modern physiological approach to neurology, but it will have a place on the medical bookshelf as an invaluable source of historical commentary and reference.

R.R.H.L.

\section{THE CASUALTY DEPARTMENT}

By T. G. Lowden, M.A., B.M., B.Ch., F.R.C.S. Pp. viii +278 , with 170 illustrations, 20 in colour. Edinburgh: E. \& S. Livingstone Ltd. 1955. 37s. 6d.

Mr. Lowden's object has been to produce a book which, by drawing on experience gained during a seven-years' study in a casualty department, will provide guidance for casualty officers. Nowadays, when the work of casualty departments has assumed far greater importance than formerly, such a book is clearly needed, and to a great extent Mr. Lowden has succeeded in his aim.

In the first 98 pages, septic conditions-always a major problem of casualty work-are admirably treated, and the place of antibiotics in treatment is clearly defined. Soft-tissue injuries, both closed and open, are next considered, and in a valuable chapter are described those simple methods of skin grafting which are suitable for use in a casualty department. Principles for the treatment of burns are laid down, and in the last sections such important matters as the organization and the legal aspects of casualty work are considered.

It is, perhaps, unfortunate that in the particular region whose casualty department $\mathrm{Mr}$. Lowden has studied, fracture treatment has been segregated to a separate accident hospital. This has meant that the treatment of even minor fractures forms no part of the present work, and this gap certainly detracts from the general usefulness of the book. Most casualty officers will have to undertake the primary treatment of fractures, and Mr. Lowden would be well advised to add to future editions a chapter dealing with the general principles and possible hazards of fracture work.

In the section dealing with injuries of the peripheral nerves, Mr. Lowden might perhaps be criticized for not taking a firmer stand against primary suture. Few casualty departments are staffed or equipped sufficiently well to permit of primary nerve suture, and general experience suggests that, even when staff are highly trained and facilities adequate, secondary suture gives the best results. It is perhaps too, a valid criticism of the chapter on 'Anaesthetics' that Mr. Lowden does not go very fully into the technique of regional anaesthesia by brachial plexus block-a technique $\frac{2}{2}$ which has proved very satisfactory in Continental clinics and whose advantages have led to an increase of its use in England.

These criticisms apart, Mr. Lowden is to be con- $\overrightarrow{\vec{c}}$ gratulated on producing a book which will certainly be useful to all those engaged in casualty work. It is to be hoped that he will in later editions somewhat $\frac{\sigma}{\overline{0}}$ enlarge the scope of the work so as to make it of $\frac{\mathcal{D}}{\sigma}$ even greater general use.

\section{PHYSIOLOGY IN DISEASES OF THE HEART $\vec{\circ}$ AND LUNGS}

By M. D. Altuschule. Revised edition. Pp. $x v+554$. London: Geoffrey Cumberlege. 흐 Harvard University Press. 1954. 6os.

That the immense and painstaking labour of collection and consideration that evidently went $\vec{\omega}$ into the making of this book was prompted by the $\mathrm{G}$ demands of senior medical undergraduates at $i \omega$ Harvard Medical School, is a tribute to the spirit of enquiry which must prevail among them.

The author collates and comments upon a mass of relevant literature divided and subdivided under the main heads of chronic cardiac decompensation, $\overrightarrow{\vec{c}}$ acute pulmonary edema, angina pectoris, cardiac $\subseteq$ arrhythmias, pericarditis, congenital and acquired $<$ cardiac defects, pulmonary fibrosis, chronic pu\& $\overrightarrow{0}$ monary emphysema, bronchial asthma, pleur or affusion, pneumothorax and pneumonia. The pror. fessed aim of the author is first, to present the facts and then to drape theory upon them; he is less concerned with the concept elaborated by a worker than by consideration of the data which he assembles. In fact, as he states in the Preface, his $\mathbb{D}$ conclusions sometimes differ from or oppose those of the worker whose findings he presents.

Success in this aim is achieved at the expense of comfortable reading. Continuity of text is frequently broken by lists of names. The focus of attention shifts rapidly from one aspect to another $\bar{\partial}$ of the subject under discussion. Emphasis waxes and wanes. It is like a series of lantern slides, each $\bar{\sigma}$ depicting a different view of the same scene, each seen too briefly for full appreciation. Many ideas $\delta$ are presented but synthesis is not attempted.

The bibliography is enormous and a most valuable source of information for those with special $\frac{}{\supset}$ interests in cardiovascular and pulmonary physi- $\frac{D}{2}$ ology and disease. More than half the pages are taken up by titled bibliographic references, arranged $\mathrm{N}$ alphabetically, by author's name, at the end of each $\Omega$ sub-section. The whole work is carefully indexed. $\mathrm{O}$

H.K.

\section{MEDICINE IN ITS HUMAN SETTING}

By A. E. Clark-Kennedy, M.D., F.R.C.P. Pp. 276 illustrated. London: Faber and Faber, Ltd. $\stackrel{\oplus}{+}$ 1954. 13s. 6d.

Written for all and any who have an interest in medicine and rather more than a slight acquaintance with its concepts, Dr. Clark-Kennedy's book must 